\title{
European ammonoid diversity questions the spreading of anoxia as primary cause for the Cenomanian/Turonian (Late Cretaceous) mass extinction
}

\author{
Monnet, Claude ; Bucher, Hugo
}

\begin{abstract}
Ammonoid diversity patterns show that the spreading of oceanic anoxia is not the initial and major kill mechanism for the Cenomanian/Turonian mass extinction as usually suggested. In the Anglo-Paris Basin and the Vocontian Basin, the drop of ammonoid species richness starts around the middle/late Cenomanian boundary, i.e. 0.75 myr before the occurrence of anoxic deepwater sediments. The stepwise extinction of first heteromorphs and then acanthoceratids is incompatible with the rise of the oxygen minimum zone. Moreover, shelf environments of these basins remained well oxygenated during the Cenomanian/Turonian boundary interval. Thus, we stress that other causative mechanisms initiated the ammonoid extinction even if anoxia subsequently participated in the demise of marine ecosystems
\end{abstract}

DOI: https://doi.org/10.1007/s00015-007-1209-1

Posted at the Zurich Open Repository and Archive, University of Zurich

ZORA URL: https://doi.org/10.5167/uzh-156157

Journal Article

Published Version

Originally published at:

Monnet, Claude; Bucher, Hugo (2007). European ammonoid diversity questions the spreading of anoxia as primary cause for the Cenomanian/Turonian (Late Cretaceous) mass extinction. Swiss Journal of Geosciences, 100(1):137-144.

DOI: https://doi.org/10.1007/s00015-007-1209-1 


\title{
European ammonoid diversity questions the spreading of anoxia as primary cause for the Cenomanian/Turonian (Late Cretaceous) mass extinction
}

\author{
Claude Monnet* \& Hugo Bucher
}

Key words: Ammonites, Cenomanian, Turonian, Europe, mass extinction, Anoxia

\begin{abstract}
Ammonoid diversity patterns show that the spreading of oceanic anoxia is not the initial and major kill mechanism for the Cenomanian/Turonian mass extinction as usually suggested. In the Anglo-Paris Basin and the Vocontian Basin, the drop of ammonoid species richness starts around the middle/late Cenomanian boundary, i.e. 0.75 myr before the occurrence of anoxic deepwater sediments. The stepwise extinction of first heteromorphs and then acanthoceratids is incompatible with the rise of the oxygen minimum zone. Moreover, shelf environments of these basins remained well oxygenated during the Cenomanian/Turonian boundary interval. Thus, we stress that other causative mechanisms initiated the ammonoid extinction even if anoxia subsequently participated in the demise of marine ecosystems.
\end{abstract}

\section{RESUME}

L'extinction de masse de la limite Cénomanien/Turonien (Crétacé supérieur) est habituellement considérée comme un exemple typique d'extinction globale causée par la remontée d'eaux anoxiques. Cependant, l'analyse des changements de biodiversité des ammonoïdés durant l'intervalle Cénomanien-Turonien inférieur démontre que cet événement océanique anoxique (OAE2) n'est pas la cause initiale et majeure de l'extinction des ammonites. Les bassins européens (Bassin anglo-parisien et Bassin vocontien) montrent que la chute de diversité (en terme de richesse spécifique) des ammonites s'amorce autour de la limite Cénomanien moyen/supérieur. Le déclin des ammonites se produit donc 0,75 million d'années avant le développement des eaux anoxiques. A ce décalage temporel entre les ammonites et l'anoxie s'ajoute une incompatibilité entre l'expansion d'eaux anoxiques vers les plateformes et le déclin prématuré des hétéromophes (plutôt pélagiques) par rapport aux acanthoceratidés (plutôt necto-benthiques). De plus, l'enregistrement stratigraphique des domaines peu profonds de ces bassins montre clairement que les eaux sont toujours largement oxygénées pendant la limite Cénomanien/Turonien. Il est donc probable que des mécanismes autres que l'anoxie doivent avoir initié l'extinction de masse de la limite Cénomanien/Turonien (au moins en ce qui concerne les ammonites), même si l'anoxie a ensuite partiellement participé au bouleversement des écosystèmes marins à cette période.

\section{Introduction}

The Cenomanian-Turonian is one of the most studied marine stratigraphic intervals in the Cretaceous. This focus is prompted by the occurrence of peculiar biotic and abiotic events, such as a moderate mass extinction (Raup \& Sepkoski 1984, 1986), the highest sea level of the Mesozoic (Haq et al. 1987), some of the highest atmospheric $\mathrm{CO}_{2}$ concentrations (Berner 1994; Bice \& Norris 2002), a temperature peak (Jenkyns et al. 1994), a global oceanic anoxic event (Arthur et al. 1987; Schlanger et al. 1987), a $\delta^{13} \mathrm{C}$ positive excursion caused by a major perturbation of the global carbon budget (Scholle \& Arthur 1980), and the deposition of organic-rich sediments (Herbin et al.
1986; Schlanger et al. 1987), among others. Therefore, the Cenomanian-Turonian is a key interval to analyze the interactions between biotic and abiotic events.

The Cenomanian/Turonian boundary (CTB) is characterized by a worldwide diversity drop of a number of groups, such as benthonic and planktonic foraminifers, calcareous nannoplankton, scleractinian corals, irregular echinoids, aragonitic rudist bivalves, and ammonoids (Hallam \& Wignall 1997). With the extinction of $26 \%$ of marine animal genera, Raup \& Sepkoski (1986) recognized this event as one of the eight major mass extinctions of the Phanerozoic. Harries \& Little (1999) reported the extinction of $79 \%$ of the macro-invertebrate species in the Western Interior Basin (USA).

Paläontologisches Institut und Museum, Universität Zürich, Karl Schmid Strasse 4, CH-8006 Zürich.

* Corresponding author: C. Monnet. E-mail: claude.monnet@pim.uzh.ch 


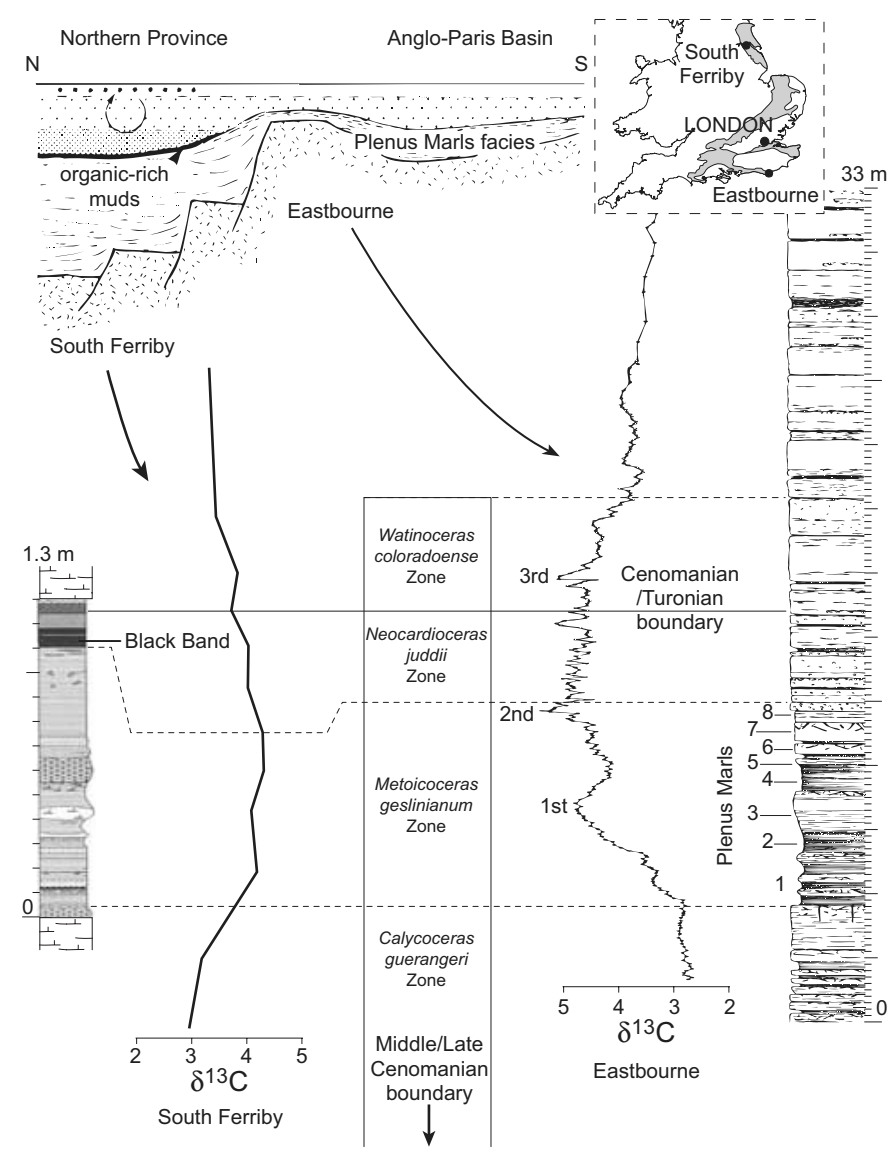

Fig. 1. Carbon isotope stratigraphy and ammonoid biostratigraphy of the Eastbourne and South Ferriby sections in the Anglo-Paris Basin. $\delta^{13} \mathrm{C}$ curve of Eastbourne after Paul et al. (1999). $\delta^{13} \mathrm{C}$ curve of South Ferriby after Wood \& Mortimore (1995).

Within the Plenus Marls (late Cenomanian) of the AngloParis Basin (north-west Europe), Jarvis et al. (1988) and Leary et al. (1989) documented the sequential decline and removal of microfaunal organisms (benthonic and planktonic foraminifers, ostracods, dinoflagellate cysts, calcareous nannofossils) in an order that corresponds to their supposed dwelling depth in the water column, thus producing a 'stepwise mass extinction' (Kauffman 1984; Hart \& Leary 1991). This depth gradient is corroborated by the present-day morphology of planktonic foraminifers (Hart 1980; Bé 1982; Hemleben et al. 1989) and by oxygen isotope studies (Corfield et al. 1990; Fisher \& Arthur 2002; Price \& Hart 2002). Hence, several authors (e.g. Kuhnt et al. 1986; Jarvis et al. 1988; Leary et al. 1989) interpreted this progressive depth-dependent extinction of the microfaunas as the effects of a rise of the Oxygen Minimum Zone (OMZ), i.e. the spreading of hypoxic/anoxic waters onto the platforms.

A significant positive excursion in the carbon isotope record (Scholle \& Arthur 1980) is also well documented during the late Cenomanian. During this interval, organic-rich sedi- ments were deposited in the deep parts of numerous basins and oceans (Schlanger et al. 1987). These black shales, which are widely regarded as the result of increased preservation of organic matter, characterize the so-called Oceanic Anoxic Event 2 (OAE2). Hence, anoxia is generally considered the major cause of the Cenomanian/Turonian boundary (CTB) mass extinction and the killing-mechanism for the extinction of numerous organisms (e.g. rudists, Philip \& Airaud-Crumière 1991; Steuber \& Löser 2000; foraminifers, Groshény \& Malartre 1997; ostracods, Babinot et al. 1998; radiolarians, Erbacher \& Thurow 1997; O'Dogherty \& Guex 2002; ammonites, Batt 1993). Therefore, the CTB mass extinction is considered a typical example of a global extinction and turnover caused by the development of anoxic waters (Kauffman \& Hart 1995).

However, Gale et al. (2000) and Smith et al. (2001) have questioned the existence of this mass extinction. They argued that the faunal turnover might essentially result from a taphonomic-preservation bias generated by the spread of hemipelagic depositional environments onto the shelves resulting from an exceptionally high sea level. Thus, turnover of microfaunas during the CTB may be related to local environmental changes and the turnovers do not necessarily record increased global extinction events. Banerjee \& Boyajian (1996) also documented the extinction of only $17 \%$ of foraminifer genera (within a binned-stage database), with a significant preferential bias toward discoid-agglutinated forms. The latter are usually known as more oxic-tolerant, therefore suggesting that anoxia may not have been the cause of the CTB foraminifer extinction. Finally, in contrast to all these interpretations, Monnet et al. (2003) documented a diversity drop of ammonoids in northwest European basins, thus supporting the existence of an extinction event. However, this drop in diversity seems to have predated the spread of anoxic waters and appears to contradict the hypothesis of Elder (1989) and Batt (1993), who argued that the anoxic event caused a stepwise demise of ammonoids. Even if the drop of ammonoid diversity documented by Monnet et al. (2003) confirms the existence of a moderate mass extinction, it casts serious doubt on the widely quoted anoxia as a kill-mechanism for all marine clades during the late Cenomanian. Here we discuss the timing of anoxia in relation to biodiversity patterns of ammonoids of the Anglo-Paris Basin, for which the model of anoxia-based extinction was initially proposed, and of the Vocontian Basin, for which black shales are well documented.

\section{Timing of anoxia}

During the Late Cretaceous, the Anglo-Paris Basin belonged to the north-European chalk sea. Conspicuous lateral lithologic changes led to the recognition of two major depositional provinces (Wood \& Smith 1978): the northern province (eastern England, North Sea and northern Germany) and the Anglo-Paris province (southern England and Paris Basin). Within these two provinces the CTB succession is differently expressed (Fig. 1): in the northern province the succession 

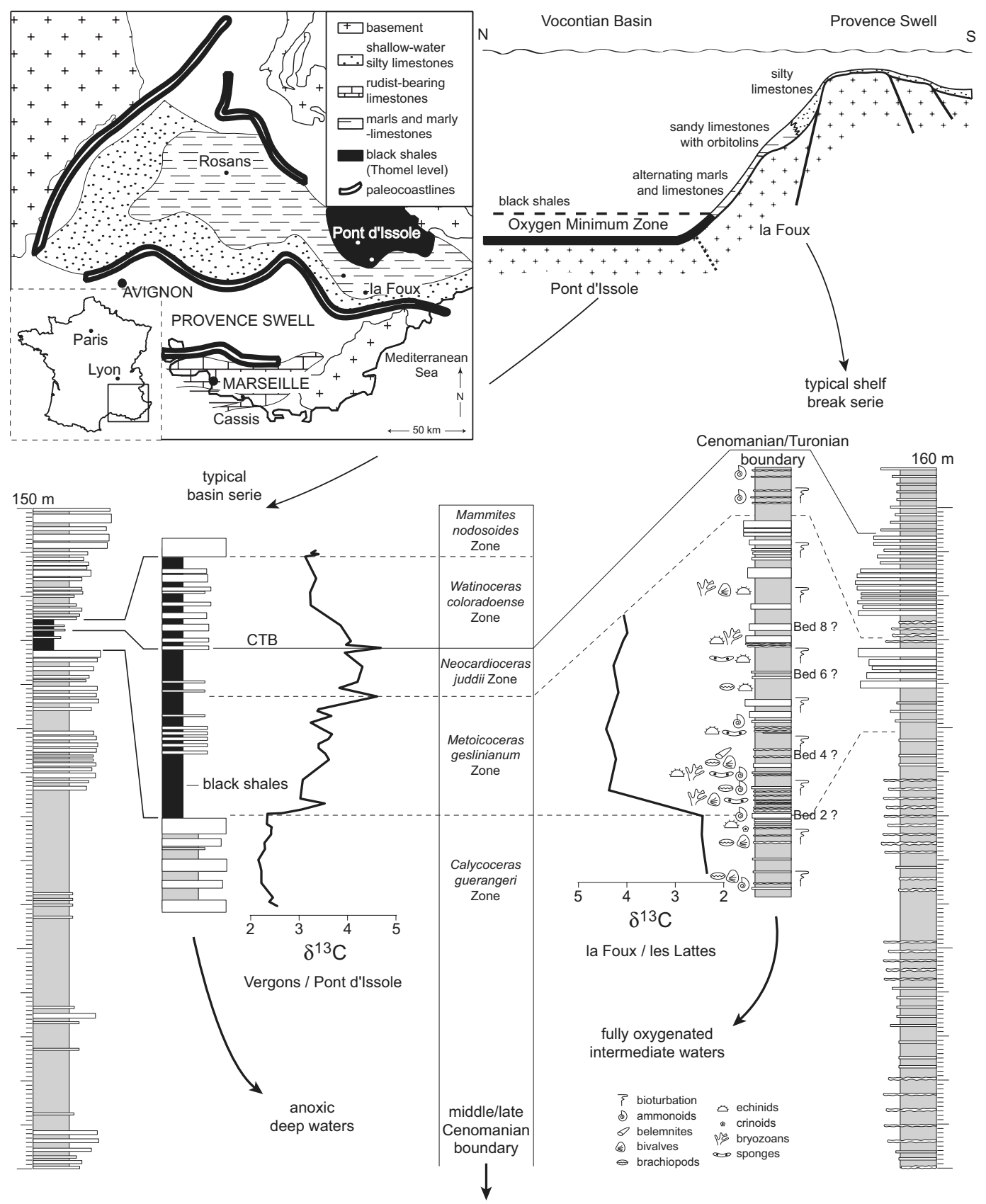

Fig. 2. Carbon isotope stratigraphy and ammonoid biostratigraphy of the la Foux and Vergons sections in the Vocontian Basin. $\delta^{13} \mathrm{C}$ curve of la Foux after Gale \& Christensen (1996). $\delta^{13} \mathrm{C}$ curve of Vergons after Morel (1998).

comprises very thin (about one metre) variegated beds including a black shale (the Black Band), while in the southern province, the equivalent succession is up $13 \mathrm{~m}$ thick, devoid of black shales, and includes the Plenus Marls and basal Holywell Beds (base of the White Chalk Formation).

The extinction model of Jarvis et al. (1988), calling upon anoxia as a kill mechanism, is essentially based on data from the Dover section in the Anglo-Paris Basin. These authors argued that the extinction phase and the development of anoxic waters occurred within the Plenus Marls. The Plenus Marls belong to the Metoicoceras geslinianum Zone (Wright \& Kennedy 1981; Paul et al. 1999). The Black Band, whose correlation in the southern province is difficult, was initially considered the equivalent of the Plenus Marls (e.g. Rowe 1904; Hart \& Bigg 1981; Hart \& Leary 1989; Jeans et al. 1991; Hart et al. 1993). However, using carbon isotope data and macrofossil evidence, Wood \& Mortimore (1995) and Morel (1998) independently demonstrated that the Black Band s.s. is younger 
than the Plenus Marls and belongs to the Neocardioceras juddii Zone, whereas the Black Band s.l. started simultaneously with the Plenus Marls (i.e. M. geslinianum Zone). This correlation mirrors the German black shale facies successions, in which the main development of black shales overlies the Plenus Bed (i.e. N. juddii Zone) but also extends into the early Turonian (e.g. Hilbrecht \& Hoefs 1986; Lehmann 1999).

The Cenomanian-early Turonian hemipelagic deposits of the Vocontian Basin, which locally may be up to $700 \mathrm{~m}$ thick, are composed of marly limestones alternating with silty marls (Fig. 2). In the latest Cenomanian these series are interrupted by several organic-rich layers (Thomel level), which vary in number from place to place (Morel 1998). These layers were deposited only in the deepest and most distal part of the basin (Crumière 1989; Crumière et al. 1990). In other basins, black shales documented were deposited in a similar depositional context (e.g. Tunisia, Robaszynski et al. 1994; Razgallah et al. 1994). In the Vocontian Basin, especially at Vergons, these layers have been intensively studied, including various methods (organic matter, Crumière 1989; Crumière et al. 1990; ichnofacies, Olivero \& Gaillard 1996; foraminifers, Tronchetti \& Groshény 1991, Groshény et al. 1992, Groshény \& Tronchetti 1993; Groshény \& Malartre 1997; ostracods, Babinot \& Groshény 1993; palynology, Courtinat et al. 1991, Svobodová et al. 1998; carbon isotopes, Morel 1998). All these studies suggest that the Thomel level was deposited under anoxic, or at least hypoxic, conditions.

Only recently, the Thomel level has been precisely dated. Initially, it was assigned to the foraminifer zone Whiteinella archeocretacea (Groshény \& Malartre 1997). Although the foraminifer zonation has a lower resolution than the ammonoid zonation, and the Vocontian sections with black shales contain only a few, non-age-diagnostic ammonoids, the Vocontian black shales coincide with the $\delta^{13} \mathrm{C}$ positive excursion (Morel 1998). This major positive excursion is recognized worldwide and spans the latest Cenomanian geslinianum and juddii ammonoid zones.

\section{Ammonoid biodiversity patterns}

Monnet et al. (2003) analyzed the biodiversity patterns of ammonoids from the Anglo-Paris Basin and the Vocontian Basin. It should be noted that their study includes data from proximal to distal environments, thus lowering the preservation bias induced by the increasing sea level characterizing the late Cenomanian interval. Their study relies on the revision of the ammonoid zonation of these two basins, including numerous sections from each basin (see Monnet \& Bucher 2002), thus lowering the sampling bias on documented ranges of ammonoids. Monnet et al. (2003) also used several statistical tests to assess the validity of the documented ammonoid biodiversity patterns.

For both basins, Monnet et al. (2003) demonstrated that during the early-middle Cenomanian, ammonoids show a high species richness characterized by a dynamic equilibrium. This equilibrium rapidly changed at the middle/late Cenomanian boundary with a diversity drop to very low values of species richness (Fig. 3). It is also important to note that separate analyses of species richness for acanthoceratids and heteromorphs, the two essential components of the Cenomanian ammonoid community ( $41 \%$ and $23 \%$, respectively), reveal that heteromorphs declined before the acanthoceratids. In the mentioned European basins, leiostraceous shells and most heteromorphs were already extinct at the middle/late Cenomanian boundary.

\section{Discussion}

The first issue is to compare diversity fluctuations of ammonoids with the timing of anoxic deposits. In both European basins, the biodiversity crisis of ammonoids started at the middle/late Cenomanian boundary (i.e. the base of the Calycoceras guerangeri Zone), while the spreading of anoxic waters onto the shelves started within the geslinianum Zone. Hence, ammonoid species richness declined one ammonoid zone before the spreading of anoxia (Fig. 3). This delay is significant, since the Calycoceras guerangeri Zone is supposed to last about 0.75 myr as established by radiometric ages from the Western Interior Basin (see Obradovitch 1993). Hence, the timing of ammonoid decline does not coincide with the development of anoxia, and anoxia alone cannot have triggered the decline of ammonoids. This decrease in ammonoid species richness may be seen as a result of a shift of facies belts caused by the late Cenomanian major flooding (see Smith et al. 2001). However, there is convincing evidence that the documented ammonoid decline is relatively unaffected by migration of facies or by preservation bias. They are documented for two basins with highly contrasted lithologies (e.g. chalks vs. limestone-marl alternations) and for each basin derived from sections ranging from proximal to distal depositional settings. Moreover, the differences in biodiversity patterns between acanthoceratids and heteromorphs suggest that there is no major preservation bias.

Most ammonoids are widely assumed to have had a nektobenthonic mode of life, and thus should have gone extinct together with microbenthonic faunas with the onset of anoxic water episodes. Many studies have also related ammonoid shell morphotypes to environmental parameters, particularly to water depth (e.g. Ziegler 1967; Donovan 1985; Batt 1989; Westermann 1996). For the case of an upward migration of a poorly oxygenated water mass, Batt (1993) argued that highly ornamented, nektobenthonic acanthoceratids should disappear first, while ancyloconic, pelagic heteromorphs should survive. From the north-west European record (see Monnet et al. 2003), the opposite pattern emerges. Hence, even if the time lag outlined above is ignored, ammonoid biodiversity patterns are not compatible with the development of anoxic waters.

These results raise the question of the influence of anoxia on the diversity of ammonoids. Since anoxic waters developed in the deepest parts of the basins, the question remains 
whether anoxia did really spread onto the platforms and how it affected the biota. The model of Jarvis et al. (1988) assumed upward migration and spreading of anoxic waters onto platforms. However, in the Vocontian Basin, the black shales are clearly restricted to the deepest part of the basin (Fig. 2; Crumière 1989) and they are missing in slope and shelf environments. During the entire geslinianum Zone the sediments of outer shelf sections, such as at La Foux-Les Lattes, are intensively bioturbated and contain highly diverse benthonic faunas, including bivalves, sponges, irregular and regular echinoids, starfishes, bryozoans, inoceramids, as well as planktonic faunas (unpub. data, Fig. 2; see also Thomel 1992 and Gale \& Christensen 1996). These faunas clearly developed under fully oxygenated conditions. It is noteworthy that the Thomel level consists of black shales alternating with bioturbated calcareous marls, which contain fish bones and intermediate-water planktonic foraminifers (Crumière 1989). This suggests that shallow environments of the Vocontian Basin were fully oxygenated. Hence, the model of a rising OMZ is not supported by data from the available sections in the Vocontian Basin, although the Thomel Level clearly indicates anoxic, or at least hypoxic, deep waters.

Initially Jarvis et al. (1988) based their model of anoxiatriggered extinction on data from the Dover section in the Anglo-Paris Basin. However, this model also takes into account data from other European basins. Although typical black shales are not present in the Dover section, Jarvis et al. (1988) argued that both sediments and microfaunas reflect the spread of oxygen-depleted environments during the Plenus Marls. However, Gale et al. (2000) argued that the decrease in diversity in microfauna, as well as changes in macrofauna, trace fossils and sedimentary geochemistry throughout the Plenus Marls interval were not related to decreasing oxygenation levels. As recalled by Smith et al. (2001), high-resolution studies are particularly sensitive to problems of stratigraphic completeness and sampling effort. Although numerous studies of various sections and basins claimed to document the progressive removal of shallower microfaunas due to the rising OMZ, the comparison of published data of various authors and from various sections of the Plenus Marls (e.g. Jarvis et al. 1988; Morel 1998; Paul et al. 1999; Keller et al. 2001) reveal that the extinction events of the various microfossil groups are rarely from the same bed. As pointed out by Gale et al. (2000) and Smith et al. (2001) the great late Cenomanian transgression may have induced local preservation biases generated by the spread of hemipelagic depositional environments onto the shelf. Local data are likely to be biased by local paleoenvironments and therefore may not reflect regional or global diversity patterns. To avoid such biases in studying the existence and the magnitude of a mass extinction, analyses should be performed at least at basin-scale in order to cover the whole array of environments (from coastline to deep basin). It is essential to note that studies of the global diversity of Cretaceous planktonic foraminifers (e.g. Hart 1999; Premoli Silva \& Sliter 1999; Hart et al. 2002) have shown that anoxic events cannot be de-

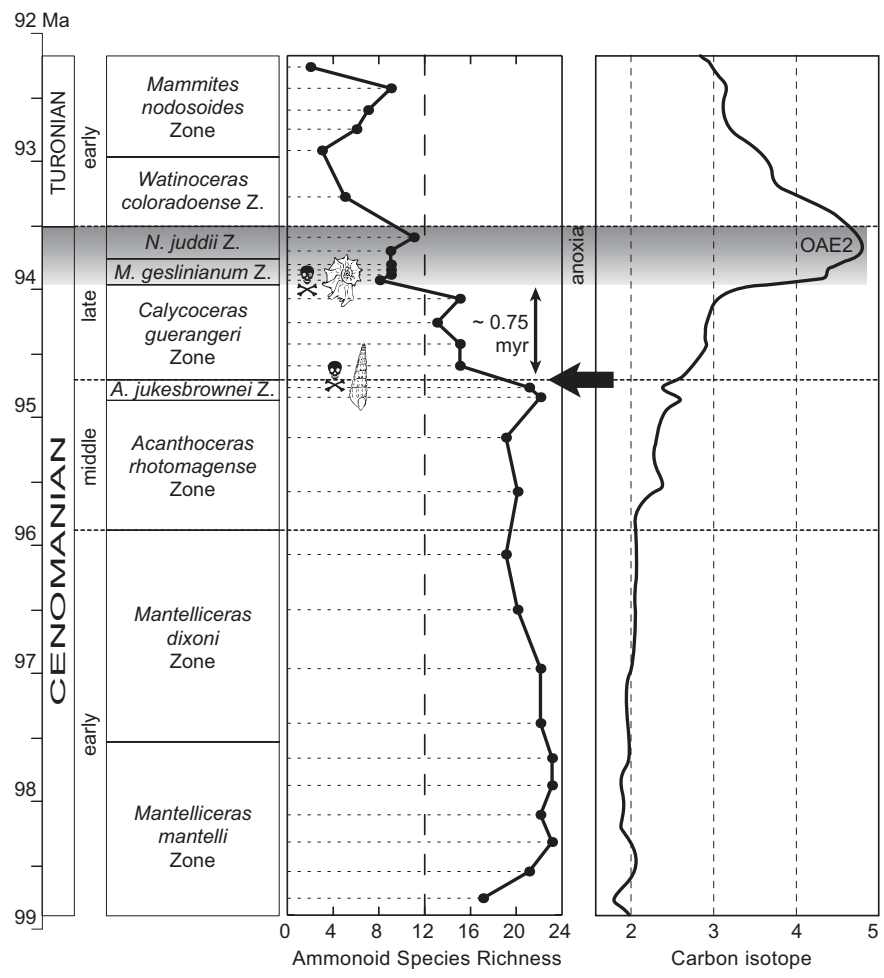

Fig. 3. Ammonoid species richness (after Monnet et al. 2003) and carbon isotope changes (after Voigt 2000) of northwest Europe during the Cenomanianearly Turonian. Note that ammonoid diversity dropdowns before the spreading of anoxia and that heteromorphs decline before acanthoceratids.

scribed as 'controlling factor' of the evolution of planktonic foraminifers. These studies emphasize that OAE2 is not associated with a drop in foraminifer diversity, but with a major turnover and a slight increase in taxonomic richness. According to Premoli Silva \& Sliter (1999), the diversification of mesotrophic species (e.g. dicarinellids and whiteinellids) and the disappearance of specialized, oligotrophic species (e.g. rotaliporids) characterize the CTB turnover. These authors interpreted these trends as an indication of a change toward less stable and more eutrophic environments culminating in OAE2.

Finally, Corfield et al. (1990) studied stable oxygen and carbon isotopes of various morphotypes of benthonic and planktonic foraminifers from the Plenus Marls from Dover (Anglo-Paris Basin). As expected by the hypothesis of Jarvis et al. (1988), Corfield et al. (1990) found interesting evidence for vertical gradients of foraminifer habitats (e.g. Rotalipora in deeper water and Hedbergella in surface water). However, Corfield et al. (1990) also documented a very good correlation of planktonic and benthonic $\delta^{13} \mathrm{C}$ records throughout the entire Plenus Marls interval, thus suggesting that during the late Cenomanian there was no change in the vertical $\delta^{13} \mathrm{C}$ gradient. Consequently, subsurface oxygenation remained unchanged during the geslinianum Zone, and there is no clear relationship between the local extinction of benthonic and 
planktonic foraminifers and macrofossil taxa and the expansion of the OMZ in the Anglo-Paris Basin. Hence, these available data do not support the model of a rising OMZ as major cause of the end-Cenomanian mass extinction.

\section{Conclusions}

The present study reveals and emphasizes several important results: (i) in both, the Anglo-Paris and Vocontian basins, the occurrence of oxygen-depleted water masses are confined to the deepest parts and limited in time to the geslinianum and juddii Zones (latest Cenomanian); (ii) in both basins shelf environments were fully oxygenated as demonstrated by oxygen and carbon isotope studies in the Anglo-Paris Basin and by abundant and highly diverse benthonic and planktonic faunas in the Vocontian Basin; (iii) in both basins the major changes of ammonoid faunas (diversity decline, evolutionary changes, taxonomic restructuring) started around the middle/late Cenomanian boundary (the guerangeri Zone), one ammonoid zone before the onset of the spreading of anoxic water masses in the deeper settings (the geslinianum Zone); and (iv) in both basins heteromorphs disappeared before acanthoceratids.

Although we agree that there is extensive evidence for widespread anoxia during the CTB interval in deep-water environments, our results rule out anoxia as the cause of the ammonoid crisis in northwest Europe. The latter predates by about 0.75 myr the evidence of anoxia in these basins. This lag is long enough to preclude anoxia as a killing-mechanism for ammonoids. Moreover, available data challenge the classic hypothesis that anoxia spread onto shelves during the late Cenomanian. Hence, even if OAE2 had contributed to the disruption of marine ecosystems and consequently to extinctions, other causative mechanisms must have initiated the moderate CTB mass extinction, at least for the ammonoid decline in north-west Europe. These results show the need to reassess the widely invoked causal link between anoxia and the moderate mass extinction at the Cenomanian/Turonian boundary.

\section{Acknowledgements}

A. Smith and M.B. Hart are thanked for their careful and constructive reviews of the manuscript. Comments by P.A. Hochuli also helped improving the final version of this work.

\section{REFERENCES}

Arthur, M.A., Schlanger, S.O. \& Jenkyns, H.C. 1987: The CenomanianTuronian Oceanic Anoxic Event, II. Palaeoceanographic controls on organic-matter production and preservation. Special Publication of the Geological Society of London 26, 401-420.

Babinot, J.F. \& Groshény, D. 1993: La limite Cénomanien-Turonien en domaine subalpin méridional: étude des ostracodes de la coupe de Vergons (sud-est France). Revue de Micropaléontologie 36, 99-108.
Babinot, J.F., Rodriguez-Lazaro, J., Floquet, M. \& Jolet, P. 1998: Corrélations entre discontinuités sédimentaires majeures et crises biologiques chez les ostracodes du sud-ouest de l'Europe au Cénomanien. Bulletin du Centre de Recherche Elf Exploration et Production 20, 349-362.

Banerjee, A. \& Boyajian, G. 1996: Changing biologic selectivity of extinction in the Foraminifera over the past 150 m.y. Geology 24, 607-610.

Batt, R. 1989: Ammonite shell morphotype distributions in the Western Interior Greenhorn Sea and some paleoecological implications. Palaios 4, $32-42$.

Batt, R. 1993: Ammonite morphotypes as indicators of oxygenation in a Cretaceous epicontinental sea. Lethaia 26, 49-63.

Bé, A.W.H. 1982: Biology of planktonic foraminifera. Studies in Geology 6, 51-89.

Berner, R.A. 1994: GEOCARB II: a revised model for atmospheric $\mathrm{CO}_{2}$ over Phanerozoic time. American Journal of Science 294, 56-91.

Bice, K.L. \& Norris, R.D. 2002: Possible atmospheric $\mathrm{CO}_{2}$ extremes of the Middle Cretaceous (late Albian-Turonian). Paleoceanography 17, doi:10.1029/2002PA000778.

Corfield, R.M., Hall, M.A. \& Brasier, M.D. 1990: Stable isotope evidence for foraminiferal habitats during the development of the Cenomanian/Turonian oceanic anoxic event. Geology 18, 175-178.

Courtinat, B., Crumière, J.P., Méon, H. \& Schaaf, A. 1991: Les associations de kystes de Dinoflagellés du Cénomanien-Turonien de Vergons (Bassin vocontien, France). Geobios 24, 649-666.

Crumière, J.P. 1989: Crise anoxique à la limite Cénomanien-Turonien dans le bassin subalpin oriental (sud-est de la France). Relation avec l'eustatisme. Geobios, Mémoire Spécial 11, 189-203.

Crumière, J.P., Crumière-Airaud, C. \& Espitalié, J. 1990: Préservation cyclique de la matière organique amorphe des sédiments au passage Cénomanien-Turonien dans le Bassin vocontien (Sud-Est France). Contrôles paléo-océanographiques. Bulletin de la Société géologique de France 6, 469-478.

Donovan, D.T. 1985: Ammonite shell form and transgression in the British Lower Jurassic. In: Bayer, U. \& Seilacher, A. (Eds.): Sedimentary and evolutionary cycles, Lecture Notes in Earth Sciences 1, Springer-Verlag, Berlin, 48-57.

Elder, W.P. 1989: Molluscan extinction patterns across the CenomanianTuronian stage boundary in the Western Interior of the United States. Paleobiology 15, 299-320.

Erbacher, J. \& Thurow, J. 1997: Influence of oceanic anoxic events on the evolution of mid-Cretaceous radiolaria in the North Atlantic and western Tethys. Marine Micropaleontology 30, 139-158.

Fisher, C.G. \& Arthur, M.A. 2002: Water mass characteristics in the Cenomanian US Western Interior seaway as indicated by stable isotopes of calcareous organisms. Palaeogeography Palaeoclimatology Palaeoecology $188,189-213$

Gale, A.S. \& Christensen, W.K. 1996: Occurrence of the belemnite Actinocamax plenus in the Cenomanian of SE France and its significance. Bulletin of the Geological Society of Denmark 43, 68-77.

Gale, A.S., Smith, A.B., Monks, N.E.A., Young, J.A., Howard, A., Wray, D.S \& Huggett, J.M. 2000: Marine biodiversity through the Late CenomanianEarly Turonian: palaeoceanographic controls and sequence stratigraphic biases. Journal of the Geological Society of London 157, 745-757.

Groshény, D. \& Malartre, F. 1997: Stratégies adaptatives des foraminifères planctoniques et cortèges sédimentaires. Application au CénomanienTuronien du bassin du Sud-Est de la France. Comptes Rendus de l'Académie des Sciences de Paris 324, 491-497.

Groshény, D. \& Tronchetti, G. 1993: La crise Cénomanien-Turonien: réponse comparée des assemblages de foraminifères benthiques de plat-forme carbonatée et de bassin dans le Sud-Est de la France. Cretaceous Research 14, 397-408.

Groshény, D., Tronchetti, G. \& Schaaf, A. 1992: Nouvelles données sur les foraminifères planctoniques et la biostratigraphie du Cénomanien-Turonien dans le Sud-Est du Bassin Vocontien. Comptes Rendus de l'Académie des Sciences de Paris 315, 773-776.

Hallam, A. \& Wignall, P.B. 1997: Mass extinctions and their aftermath. Oxford University Press, Oxford, $320 \mathrm{pp}$ 
Haq, B.U., Hardenbol, J. \& Vail, P.R. 1987: Chronology of fluctuating sea levels since the Triassic. Science 235, 1156-1167.

Harries, P.J. \& Little, C.T.S. 1999: The early Toarcian (Early Jurassic) and the Cenomanian-Turonian (Late Cretaceous) mass extinctions: similarities and contrasts. Palaeogeography Palaeoclimatology Palaeoecology 154, $39-66$.

Hart, M.B. 1980: A water depth model for the evolution of the planktonic Foraminiferida. Nature 286, 252-254.

Hart, M.B. 1999: The evolution and biodiversity of Cretaceous planktonic Foraminiferida. Geobios 32, 247-255.

Hart, M.B. \& Bigg, P.J. 1981: Anoxic events in the late Cretaceous Chalk seas of north-west Europe. In: Neale, J.W. \& Brazier, M.D. (Eds.): Microfossils from Recent and Fossil shelf seas, British Micropalaeontological Society, New York, 177-185.

Hart, M.B. \& Leary, P.N. 1989: The stratigraphic and palaeogeographic setting of the late Cenomanian 'anoxic' event. Journal of the Geological Society of London 146, 305-310.

Hart, M.B. \& Leary, P.N. 1991: Stepwise mass extinctions: the case for the Late Cenomanian event. Terra Nova 3, 142-147.

Hart, M.B., Dodsworth, P. \& Duane, A.M. 1993: The late Cenomanian event in eastern England. Cretaceous Research 14, 495-508.

Hart, M.B., Oxford, M.J. \& Hudson, W. 2002: The early evolution and palaeobiogeography of Mesozoic planktonic foraminifera. Special Publication of the Geological Society of London 194, 115-125.

Hemleben, C., Spindler, M. \& Anderson, O.R. 1989: Modern planktonic foraminifera. Springer Verlag, Berlin, $237 \mathrm{pp}$.

Herbin, J.P., Montadert, L., Müller, C., Gomez, R., Thurow, J. \& Wiedmann, J. 1986: Organic-rich sedimentation at the Cenomanian-Turonian boundary in oceanic and coastal basins in the North Atlantic and Tethys. Special Publication of the Geological Society of London 21, 389-422.

Hilbrecht, H. \& Hoefs, J. 1986: Geochemical and palaeontological studies of the $\delta^{13} \mathrm{C}$ anomaly in Boreal and North Tethyan Cenomanian-Turonian sediments in Germany and adjacent areas. Palaeogeography Palaeoclimatology Palaeoecology 53, 169-189.

Jarvis, I., Carson, G.A., Cooper, M.K.E., Hart, M.B., Leary, P.N., Tocher, B.A., Horne, D. \& Rosenfeld, A. 1988: Microfossil assemblages and the Cenomanian-Turonian (late Cretaceous) Oceanic Anoxic Event. Cretaceous Research 9, 3-103.

Jeans, C.V., Long, D., Hall, M.A., Bland, D.J. \& Cornford, C. 1991: The geochemistry of the Plenus Marls at Dover, England: evidence of fluctuating oceanographic conditions and of glacial control during the development of the Cenomanian-Turonian $\delta^{13} \mathrm{C}$ anomaly. Geological Magazine 128, 603-632.

Jenkyns, H.C., Gale, A.S. \& Corfield, R.M. 1994: Carbon- and oxygen-isotope stratigraphy of the English Chalk and the Italian Scaglia and its palaeoclimatic significance. Geological Magazine 131, 1-34.

Kauffman, E.G. 1984: Paleobiogeography and evolutionary response dynamic in the Cretaceous Western Interior Seaway of North America. Special Paper of the Geological Association of Canada 27, 273-306.

Kauffman, E.G. \& Hart, M.B. 1995: Cretaceous bio-events. In: Walliser, O.H. (Ed.): Global events and event stratigraphy in the Phanerozoic: results of the International Interdisciplinary co-operation in the IGCP Project 216, Springer Verlag, Berlin, 285-304.

Keller, G., Han, Q., Adatte, T. \& Burns, S.J. 2001: Palaeoenvironment of the Cenomanian-Turonian transition at Eastbourne, England. Cretaceous Research 22, 391-422.

Kuhnt, W., Thurow, J., Wiedmann, J. \& Herbin, J.P. 1986: Oceanic anoxic conditions around the Cenomanian/Turonian boundary and the response of the biota. Mitteilungen aus dem Geologisch-Paläontologischen Institut der Universität Hamburg 60, 205-246.

Leary, P.N., Carson, G.A., Cooper, M.K.E., Hart, M.B., Horne, D., Jarvis, I., Rosenfeld, A. \& Tocher, B.A. 1989: The biotic response to the late Cenomanian oceanic anoxic event; integrated evidence from Dover, SE England. Journal of the Geological Society of London 146, 311-317.

Lehmann, J. 1999: Integrated stratigraphy and palaeoenvironment of the Cenomanian-Lower Turonian (Upper Cretaceous) of northern Westphalia, North Germany. Facies 40, 25-70.
Monnet, C. \& Bucher, H. 2002: Cenomanian (early Late Cretaceous) ammonoid faunas of Western Europe. Part I: biochronology (unitary associations) and diachronism of datums. Eclogae geologicae Helvetiae 95, $57-73$.

Monnet, C., Bucher, H., Escarguel, G. \& Guex, J. 2003: Cenomanian (early Late Cretaceous) ammonoid faunas of Western Europe. Part II: diversity patterns and the end-Cenomanian anoxic event. Eclogae geologicae Helvetiae 96, 381-398.

Morel, L. 1998: Stratigraphie à haute résolution du passage CénomanienTuronien. Unpublished PhD Thesis, University of Paris VI, 223 pp.

O'Dogherty, L. \& Guex, J. 2002: Rates and pattern of evolution among Cretaceous radiolarians: relations with global paleoceanographic events. Micropaleontology 48, Supplément 1, 1-22.

Obradovitch, J.D. 1993: A Cretaceous time scale. Special Paper of the Geological Association of Canada 39, 379-396.

Olivero, D. \& Gaillard, C. 1996: Ichnologie du passage Cénomanien-Turonien. Exemple de la coupe de Vergons (Alpes de Haute-Provence, SE France). Comptes Rendus de l'Académie des Sciences de Paris 322, 1005-1012.

Paul, C.R.C., Lamolda, M.A., Mitchell, S.F., Vaziri, M.R., Gorostidi, A. \& Marshall, J.D. 1999: The Cenomanian-Turonian boundary at Eastbourne (Sussex, UK): a proposed European reference section. Palaeogeography Palaeoclimatology Palaeoecology 150, 83-121.

Philip, J. \& Airaud-Crumière, C. 1991: The demise of rudist-bearing carbonate platforms at the Cenomanian/Turonian boundary: a global control. Coral Reefs 10,115-125.

Premoli Silva, I. \& Sliter, W.V. 1999: Cretaceous paleoceanography: evidence from planktonic foraminiferal evolution. Special Paper of the Geological Society of America 332, 301-328.

Price, G.D. \& Hart, M.B. 2002: Isotopic evidence for Early to mid-Cretaceous ocean temperature variability. Marine Micropaleontology 46, 45-58.

Raup, D.M. \& Sepkoski, J.J. 1984: Periodicity of extinctions in the geologic past. Proceedings of the National Academy of Sciences 81, 801-805.

Raup, D.M. \& Sepkoski, J.J. 1986: Periodic extinction of families and genera. Science 231, 833-836.

Razgallah, S., Philip, J., Thomel, G., Zaghbib-Turki, D., Chaabani, F., Ben Haj Ali, N. \& M'Rabet, A. 1994: La limite Cénomanien-Turonien en Tunisie centrale et méridionale: biostratigraphie et paléoenvironements. Cretaceous Research 15, 507-533.

Robaszynski, F., Caron, M., Amédro, F., Dupuis, C., Hardenbol, J., Gonzalez Donoso, J.M., Linares, D. \& Gartner, S. 1994: Le Cénomanien de la région de Kalaat Senan (Tunisie centrale): litho-biostratigraphie et interprétation séquentielle. Revue de Paléobiologie 12, 351-505.

Rowe, A.W. 1904: The zones of the White Chalk of the English Coast. 4. Yorkshire. Proceedings of the Geologists' Association 20, 193-296.

Schlanger, S.O., Arthur, M.A., Jenkyns, H.C. \& Scholle, P.A. 1987: The Cenomanian-Turonian Oceanic Anoxic Event, I. Stratigraphy and distribution of organic carbon-rich beds and the marine $\delta^{13} \mathrm{C}$ excursion. Special Publication of the Geological Society of London 26, 371-399.

Scholle, P.A. \& Arthur, M.A. 1980: Carbon isotope fluctuations in Cretaceous pelagic limestones: potential stratigraphic and petroleum exploration tool. American Association of Petroleum Geologists Bulletin 64, 67-87.

Smith, A.B., Gale, A.S. \& Monks, N.E.A. 2001: Sea-level change and rockrecord bias in the Cretaceous: a problem for extinction and biodiversity studies. Paleobiology 27, 241-253.

Steuber, T. \& Löser, H. 2000: Species richness and abundance patterns of Tethyan Cretaceous rudist bivalves (Mollusca: Hippuritacea) in the central-eastern Mediterranean and Middle East, analysed from a palaeontological database. Palaeogeography Palaeoclimatology Palaeoecology 162 , 75-104.

Svobodová, M., Méon, H. \& Pacltová, B. 1998: Characteristics of palynospectra of the Upper Cenomanian-Lower Turonian (anoxic facies) of the Bohemian and Vocontian Basins. Bulletin of the Czech Geological Survey 73, 229-251.

Thomel, G. 1992: Ammonites du Cénomanien et du Turonien du Sud-Est de la France. Tome 1. Le Cénomanien des chaînes subalpines méridionales et de la Provence orientale. Eléments de biostratigraphie (ammonites). Serre, Nice, $422 \mathrm{pp}$. 
Tronchetti, G. \& Groshény, D. 1991: Les assemblages de foraminifères benthiques au passage Cénomanien-Turonien à Vergons, S.E. France. Geobios 24, 13-31.

Voigt, S. 2000: Cenomanian-Turonian composite $\delta^{13} \mathrm{C}$ curve for Western and Central Europe: the role of organic and inorganic carbon fluxes. Palaeogeography Palaeoclimatology Palaeoecology 160, 91-104.

Westermann, G.E.G. 1996: Ammonoid life and habitat. In: Landman, N.H. et al. (Eds.): Ammonoid paleobiology, Plenum Press, New York, 608-710.

Wood, C.J. \& Mortimore, R.N. 1995: An anomalous Black Band succession (Cenomanian-Turonian boundary interval) at Melton Ross, Lincolnshire, eastern England and its international significance. Berliner geowissenschaftliche Abhandlungen Reihe E 16, 277-287.

Wood, C.J. \& Smith, E.G. 1978: Lithostratigraphical classification of the Chalk in North Yorkshire, Humberside and Lincolnshire. Proceedings of the Yorkshire Geological Society 42, 263-287.
Wright, C.W. \& Kennedy, W.J. 1981: The Ammonoidea of the Plenus Marls and the Middle Chalk. Monograph of the Palaeontographical Society of London 560, 148 pp.

Ziegler, B. 1967: Ammoniten-Okologie am Beispiel des Oberjura. Geologische Rundschau 56, 439-464.

Manuscript received October 02, 2006

Manuscript accepted January 18, 2007

Published Online First April 18, 2007

Editorial handling: M.J. Benton \& J.-P. Billon-Bruyat 